\title{
Europe, globalization and the Lisbon Agenda: an introduction
}

\section{Maria João Rodrigues}

\section{I.1 THE POINT OF DEPARTURE OF THE LISBON STRATEGY}

The Lisbon Strategy adopted by the European Council in 2000 was designed to address the following main question: is it possible to update Europe's development strategy so that we can rise to the new challenges resulting from globalization, technological change and population ageing, while preserving European values? In the new emerging paradigm, knowledge and innovation are the main sources both of wealth and divergence between nations, companies and individuals. Europe has been losing ground to the United States, but this does not mean that Europe must follow that model.

The purpose was to define a European path towards the new innovation and knowledge-based economy, taking advantage of distinctive attributes, including the preservation of social cohesion and cultural diversity as well as technological options. A critical step was the establishment of a competitive platform to sustain the European social model, which also had to be renewed.

In order to fulfil this goal, institutional reforms were necessary to tap into the potential of this new paradigm while avoiding the risks of widening the social divide. These reforms included innovation of norms regulating international trade and competition, of social models, and of education systems. Moreover, institutional reforms had to internalize the level of integration in each Member State which had been accomplished through the single market and the single currency. This means that some level of European coordination was required to carry out institutional reforms, while respecting national specificity. A multilevel governance system was needed to permit an interaction between the various levels (namely, the European, national and local).

In order to find an answer to the initial question, an extensive intellectual and political review was undertaken of Europe's political agenda and the 
main Community policy documents in light of the most up-to-date social science findings. European politicians, top officials, and experts with a broad experience in these fields were involved in this task (Rodrigues, 2002). Their purpose was to ascertain which institutional reforms could change how European societies are currently regulated, so as to pave the way for a new development trajectory geared towards the creation of a knowledgebased economy. But it was necessary for key ideas to result in political decisions and action. The entire Portuguese EU presidency in 2000 was tailored to achieve this goal, throughout its two European councils, 14 councils of ministers, seven ministerial conferences, several sessions of the European Parliament, and a high-level forum grouping the major stakeholders in Europe and the Member States.

It is relevant to recall the exact terms of the new strategic goal and overall strategy defined by the Lisbon European Council on 23-24 March 2000. To quote its Conclusions: 'The Union has today set itself a new strategic goal for the next decade: to become the most competitive and dynamic knowledge-based economy in the world capable of sustainable economic growth with more and better jobs and greater social cohesion.' This quote is important because it clarifies that, contrary to some vulgarizations, the strategic goal defined in Lisbon was not for Europe 'to become the most competitive' (although this was a central objective) but rather to achieve this particular combination of strong competitiveness with the other features mentioned above. So it is by reference to this combination that the European path must be defined, and that Europe can do better than its counterparts, notably the USA. This should have methodological implications for the indicators selected to compare relative performances.

Such a complex goal required a particular strategy, which was defined in the following terms:

Achieving this goal requires an overall strategy aimed at: preparing the transition to a knowledge-based economy and society by better policies for the information society and R\&D [research and development], as well as by stepping up the process of structural reform for competitiveness and innovation and by completing the internal market; modernizing the European social model, investing in people and combating social exclusion; sustaining the healthy economic outlook and favourable growth prospects by applying an appropriate macroeconomic policy mix.

Later on, the Spring European Council of Stockholm in 2001 emphasized the concern with the environment and sustainable development.

The implementation of the Lisbon Strategy should therefore be comprehensive, balanced, based on the synergies, but also focused on clear priori- 
ties, and adaptable to the diversity of national situations. One can argue that this seems to be about 'squaring the circle', because there are too many trade-offs between these different objectives. There certainly are difficult trade-offs requiring difficult political choices in the short run, but it is important to learn from some successful cases.

Success often depends on the capacity to overcome a specific trade-off by developing a specific synergy. For instance, it is possible to overcome the trade-offs between macroeconomic stability and growth, by creating some fiscal room for manoeuvre for key public investments to enhance growth potential; between productivity and employment, by fostering innovation in products and services and not just in technological process; between growth and cohesion, by shifting cohesion policies to equip the least favoured individuals and regions with more capabilities; between flexibility and security in the labour market, by negotiating new kinds of 'flexicurity' arrangements; and between growth and environment, by turning sustainable development into new opportunities for investment and growth. These examples show that the successful implementation of the Lisbon Strategy requires a comprehensive approach, with implications for both policies and governance.

\section{I.2 THE LISBON AGENDA}

The Lisbon Strategy was also translated into new general orientations for the following policies: information society, research and development, innovation, enterprise, single market, education, employment, social protection, social inclusion, the environment, and transport and telecommunications (see Box I.1).

It is important to keep in mind this list of policies because each has a specific institutional basis in the European Union (EU), as well as a network of specialized people involved in public administration and civil society across all Member States. Over the years that followed, these general orientations were transformed by these key actors into operational instruments, directives, regulations, Community programmes and action plans (see Table I.1) which are often designated as the 'Lisbon Agenda'.

\section{I.3 A SHORT HISTORY OF THE LISBON AGENDA}

The Lisbon Agenda was developed to address the evolving challenges posed by a global economy, by progressively adapting several existing policies, institutional and financial instruments to its strategic priorities. The 


\section{BOX I.1 THE LISBON AGENDA}

A. Elaborating a policy for the information society aimed at improving citizens' standards of living, with concrete applications in the fields of education, public services, electronic commerce, health and urban management. Giving renewed impetus to the spread of information technologies in companies (namely e-commerce and knowledge management tools); establishing the goal of deploying advanced telecommunications networks, and democratizing access to the Internet, on the one hand, and producing content that adds value to Europe's cultural and scientific heritage, on the other.

B. Creating an R\&D policy whereby the existing Community programme and national policies converge to create a European research area by networking R\&D programmes and institutions.

C. Strongly prioritizing an innovation policy and the creation of a Community patent.

D. Designing an enterprise policy that transcends the existing Community programme, combining it with the coordination of national policies to create better conditions for entrepreneurship - namely administrative simplification, better regulation, access to venture capital or manager training.

E. Promoting economic reforms that target the creation of growth and innovation potential, improve financial markets to support new investments, and complete Europe's internal market by liberalizing the basic sectors while respecting the public service inherent to the European model.

F. Defining new priorities for national education policies (turning schools into open learning centres, providing support for each and every population group, and using the Internet and multimedia; in addition, Europe should adopt a framework of new basic skills and create a European diploma to combat computer illiteracy).

G. Intensifying active employment policies to make lifelong training generally available and expanding employment in services as a significant source of job creation, and improving adaptability and promoting equal opportunities for women and men. The key target of raising Europe's employment 
rate was adopted to reduce the unemployment rate and to consolidate the sustainability of the social protection systems.

$\mathrm{H}$. Organizing cooperation between Member States to modernize social protection, identifying reforms to address common problems such as matching pension systems with population ageing.

I. Elaborating national plans to take action against all dimensions of social exclusion (including education, health and housing) and meeting the requirements of target groups specific to each national situation.

J. The environmental dimension was added to the economic and social dimensions of the Lisbon Agenda by the European Council of Stockholm in 2001, establishing a comprehensive strategy for sustainable development.

implementation of the Lisbon Strategy went through different phases, its time horizon being 2010 .

The first phase focused on: translating the Lisbon European Council conclusions into policy instruments of the European Union, adding the environmental dimension and building on the sustainable development approach; preliminary implementation in the Member States (still very imbalanced from area to area, and from Member State to Member State); introducing the basic mechanisms for implementation (Spring European Council, reorganization of the Council formations and schedules, involvement of the European Parliament and the other European institutions, the social partners and organized civil society at the European level, development of the open method of coordination - OMC - tools); and introducing stronger mechanisms in the new European Constitutional Treaty, which were later retained in the Lisbon Treaty.

The second phase began with the mid-term review in 2005, putting the focus on implementation at the national level, including in the new Member States. This new focus called for stronger interface between the European and the national levels of governance, with implications for the behaviour of the main actors. This phase also served to clarify the financial basis of the implementation of the Lisbon Strategy.

A third phase began after 2007, and has consisted of fine-tuning implementation on the ground, to take into account the final outcome of the new European Treaty, and thus adapt to the new context and to prepare for the period after 2010 . 
Table I.1 Modes of governance by policy

\begin{tabular}{|c|c|c|c|c|c|}
\hline $\begin{array}{l}\text { Policies } \\
\text { Instru- } \\
\text { ments }\end{array}$ & $\begin{array}{l}\text { Monetary } \\
\text { (euro area) }\end{array}$ & Budget & $\begin{array}{l}\text { Internal } \\
\text { market }\end{array}$ & Competitiveness & Industrial \\
\hline $\begin{array}{l}\text { Exclusive EU } \\
\text { competence }\end{array}$ & $X$ & & & $X$ & \\
\hline $\begin{array}{l}\text { Directives, } \\
\text { regulations }\end{array}$ & & $\mathrm{X}$ & $\mathrm{X}$ & $X$ & $\mathrm{X}$ \\
\hline Guidelines & & $X$ & & & $X$ \\
\hline \multicolumn{6}{|l|}{$\begin{array}{l}\text { Common } \\
\text { objectives }\end{array}$} \\
\hline $\begin{array}{l}\text { EU program- } \\
\text { mes }\end{array}$ & & & & & $\mathrm{X}$ \\
\hline \multicolumn{6}{|l|}{$\begin{array}{l}\text { Reinforced } \\
\text { cooperation }\end{array}$} \\
\hline \multicolumn{6}{|l|}{$\begin{array}{l}\text { Intergovern- } \\
\text { mental } \\
\text { cooperation }\end{array}$} \\
\hline $\begin{array}{l}\text { National } \\
\text { reform } \\
\text { programmes }\end{array}$ & & $X$ & & & $\mathrm{X}$ \\
\hline \multicolumn{6}{|l|}{$\begin{array}{l}\text { National } \\
\text { sectoral } \\
\text { programmes }\end{array}$} \\
\hline $\begin{array}{l}\text { National } \\
\text { budgets }\end{array}$ & & $\mathrm{X}$ & & & \\
\hline $\begin{array}{l}\text { Structural } \\
\text { funds }\end{array}$ & & & & & $\mathrm{X}$ \\
\hline $\begin{array}{l}\text { European } \\
\text { frameworks }\end{array}$ & & & & & \\
\hline
\end{tabular}

In fact, in 2001 and 2002, the Lisbon Strategy was transformed into an operational agenda by the Commission and the Council, which mobilized several available instruments and developed the OMC in 11 policy fields: from information society, research, innovation and enterprise policy, to education, employment, social protection and environmental policy. This process of policy-making and implementation also involved the other European institutions and stakeholders and their national counterparts. The new Member States were also involved from 2002 onwards. Nevertheless, from the beginning, the implementation has been very unequal in the various Member States and policy fields from the outset. 


Innovation $\begin{aligned} & \text { Environment, Research } \\ & \text { energy }\end{aligned} \quad \begin{aligned} & \text { Education, Employment } \\ & \text { learning }\end{aligned} \quad \begin{aligned} & \text { Social } \\ & \text { protection }\end{aligned}$

\begin{tabular}{|c|c|c|c|c|c|}
\hline & $X$ & $X$ & & $X$ & $X$ \\
\hline$X$ & $X$ & $X$ & $\begin{array}{l}X \\
X\end{array}$ & $X$ & $\mathrm{X}$ \\
\hline$X$ & $X$ & $X$ & $X$ & $X$ & $X$ \\
\hline \multirow[t]{2}{*}{$X$} & & $X$ & & & \\
\hline & & $X$ & & & \\
\hline \multirow[t]{2}{*}{$X$} & $X$ & $X$ & $X$ & $X$ & $X$ \\
\hline & $X$ & & & & $X$ \\
\hline$X$ & & $X$ & $X$ & $X$ & X \\
\hline$X$ & $X$ & $X$ & $X$ & $X$ & $X$ \\
\hline & & & $X$ & & \\
\hline
\end{tabular}

The year 2003 was particularly marked by the debate on the possible connections between the Lisbon Agenda and the new Treaty being prepared by the Convention on the Future of Europe namely: the General Affairs Council, coordination between economic, employment and social policies, the instrument mix in each policy, and the basic tools of the OMC.

In parallel, some cooperation initiatives with partner countries, such as China and Brazil, initiated an exchange of experiences with development agendas, in which the Lisbon Strategy served as a point of reference.

In 2004, since implementation seemed to be hindered by inadequate financial means, there was another debate about the implications of the 
Lisbon Strategy for the future Community budget, the priorities for the following generation of Community programmes and structural funds, state aid reform and, last but not least, the reform of the Stability and Growth Pact. In the meantime, the planned mid-term review of the Lisbon Agenda was also prepared.

In 2005, with the mid-term review conducted by the Luxembourg presidency, major decisions were taken to foster the implementation of the Agenda, notably to clarify priorities and launch new political and financial instruments. More specifically, new integrated guidelines were adopted for economic and employment policies, and Member States were invited to turn them into national reform programmes, adapting the Lisbon Strategy to national specificities. A new set of financial instruments was also adopted, comprising the Community budget, the guidelines for structural funds, the rules for state aid and a revised Stability and Growth Pact (the renewed content of the Lisbon Agenda is presented in section I.4 below).

During 2006, the focus was on implementation, involving the creation of new government structures for the Lisbon coordinators, the involvement of more stakeholders at the national level, the mobilization of new financial means, and the development of new policy measures. There was also a stronger political focus on energy and the environment because of increased evidence of climate change.

In 2007, there was a positive trend in terms of growth and net employment creation, but its sustainability depended on more growth potential generated by structural reforms, and on the broader trends in the global economy. In 2008, within the framework of the trio of presidencies (the German, Portuguese and Slovenian), a new cycle of the Lisbon Agenda was launched for the period 2008-10, with a stronger emphasis on the environment and energy, and social cohesion as well as on the external dimension of the Lisbon Strategy. The European Council of March 2008 (see its conclusions in Appendix 2) also defined a mandate to initiate a reflection on the future of the Lisbon Strategy in the post-2010 period.

Several structural reforms are now addressing social protection, health systems, public administration, financial systems, research and education, and labour markets but they are still insufficient and, above all, imbalanced when comparing policy fields and countries. Nevertheless, it is already possible to conclude that the Member States that have been most effective in implementing the kind of reforms outlined in the Lisbon Agenda are also those reaping the most benefits in terms of growth, job creation and sustainable development. 


\section{I.4 THE LISBON AGENDA AFTER THE MID-TERM REVIEW}

The Lisbon Agenda was reshaped by the mid-term review in 2004-05, under the Luxembourg presidency, in order to provide answers to the main problems which had been identified (Kok, 2004; Sapir, 2004): blurring of the strategic objectives; inflation of priorities and measures; lack of implementation, coordination and participation mechanisms; and lack of financial incentives.

\section{Clarifying Strategic Objectives}

The first question related to the relevance of the Strategy itself. Was the Lisbon Strategy still relevant in light of new emerging challenges? Clearly, the global landscape was changing, and the Lisbon Strategy has had to take on board the emergence of new competitive players, as well as more evident population ageing trends. But the Spring European Council under the presidency of Luxembourg concluded that the general approach remained valid and was, indeed, becoming more urgent than before: 'Europe must renew the basis of its competitiveness, increase its growth potential and its productivity and strengthen social cohesion, placing the main emphasis on knowledge, innovation and the optimization of the human capital' (Council 7619/05, § 5). So stepping up the transition to a knowledgeintensive society remained the central priority. Within the more general context of sustainable development principles, there was also an emphasis on the need to improve the synergies between the economic, social and environmental dimensions of the strategy (Council 7619/05). It was concluded that the Strategy should refocus on growth and employment, however, with some implications for the definition of political priorities, as shown below.

\section{Defining Political Priorities}

After the mid-term review, the major political priorities of the Lisbon Strategy for growth and jobs were: generating knowledge and innovation as engines of sustainable growth; turning Europe into a more attractive place to invest and work; and creating more and better jobs. To these goals, a further macroeconomic policy strand was added, under the label 'Macroeconomic policies for growth and jobs'. A list of 24 guidelines, the so-called 'broad economic policy guidelines' and the 'employment guidelines', were elaborated to promote these four political priorities based on Treaty-based instruments (see Box I.2, and Council 10667/05 and $10205 / 05)$. 


\section{BOX I.2 THE LISBON STRATEGY: INTEGRATED GUIDELINES FOR GROWTH AND JOBS}

\section{Macroeconomic Policies for Growth and Jobs}

1. To secure economic stability for sustainable growth.

2. To safeguard economic and fiscal sustainability as a basis for increased employment.

3. To promote a growth- and employment-orientated and efficient allocation of resources.

4. To ensure that wage developments contribute to macroeconomic stability and growth.

5. To promote greater coherence between macroeconomic, structural and employment policies.

6. To contribute to a dynamic and well-functioning EMU.

\section{Knowledge and Innovation: Engines of Sustainable Growth}

7. To increase and improve investment in $R \& D$, in particular by private business.

8. To facilitate all forms of innovation.

9. To facilitate the spread and effective use of ICT, and build a fully inclusive information society.

10. To strengthen the competitive advantages of its industrial base.

11. To encourage the sustainable use of resources, and strengthen the synergies between environmental protection and growth.

\section{Making Europe a More Attractive Place to Invest and Work}

12. To extend and deepen the internal market.

13. To ensure open and competitive markets inside and outside Europe, and to reap the benefits of globalization.

14. To create a more competitive business environment and encourage private initiative through better regulation.

15. To promote a more entrepreneurial culture, and create a supportive environment for SMEs.

16. To expand and improve European infrastructure, and complete priority cross-border projects. 


\section{More and Better Jobs}

17. To implement employment policies aimed at achieving full employment, improving quality and productivity at work, and strengthening social and territorial cohesion.

18. To promote a life-cycle approach to work.

19. To ensure inclusive labour markets, enhance work attractiveness, and make work pay for job-seekers, including disadvantaged people, and the inactive.

20. To improve matching of labour market needs.

21. To promote flexibility combined with employment security, and reduce labour market segmentation, having due regard to the role of the social partners.

22. To ensure employment-friendly labour cost developments and wage-setting mechanisms.

23. To expand and improve investment in human capital.

24. To adapt education and training systems in response to new competence requirements.

Source: Council of the European Union, 10667/05.

Thus, for the first time, the EU had an integrated package of guidelines governing its economic and social policies based on Treaty-based instruments. There was a long process of maturation that made this major political development possible, the latter then advancing because of recognition that better levels of implementation were necessary.

\section{Fostering Implementation}

It was in the 1990s that the aim of defining coordinated guidelines for economic and social policies emerged in the EU, with the preparation of economic and monetary union. During the Lisbon European Council in 2000, political conditions were still not ripe for the adoption of an economic and social strategy based on more compulsory instruments such as Treaty-based guidelines. This is what led to the creation of the new open method of coordination (OMC) (Council SN 100/00 and Presidency 9088/00), which is based on: the identification of common objectives or guidelines; their translation into national policies, adapted to national specificities; and the creation of a monitoring process based on common indicators, the identification of best practices, and peer review. Despite some shortcomings, including bureaucratization and 
simplistic benchmarking, the development of this method in 11 policy fields after 2000 was instrumental in building the necessary consensus about the strategic challenges that Europe faced, and the key reforms that it had to undertake. In 2005, debate about the implementation and coordination gap had advanced sufficiently to turn some of the most important 'soft' guidelines into 'hard' Treaty-based guidelines (Council, 10667/05 and 10205/05).

In this way, the OMC has played a role in building a European dimension, instituting a learning process, and promoting some convergence, albeit with consideration for national differences. Has the OMC run its course now? The answer is no (Council 7619/05 $339 \mathrm{~d} /$ and Commission). The OMC can be used when necessary, allowing the policy-making process to operate on two levels, one more formal and precise than the other, ensuring that there is a necessary political refocusing with implementation.

A second important development regarding instruments for implementation concerns the national reform programmes prepared by the Member States in the autumn of 2005 . These programmes set out a comprehensive strategy for the implementation of the integrated guidelines, adapting them to the national context. In addition to outlining political priorities and measures, they also outline the roles that the various stakeholders are to play, the budgetary resources that are needed, including structural funds linked to stability and convergence programmes. It is stipulated that the preparation, implementation and monitoring of national programmes should involve all key political institutions and civil society and, when appropriate, a national coordinator should be appointed. All Member States must present annual follow-up reports, which provide a basis for a general report that the European Commission must present to each Spring European Council. ${ }^{1}$

The Community Lisbon Programme is the final building block for implementation. It brings together for the first time all the regulatory and financing actions and policy developments to be launched at the European level, to ensure the implementation of the Lisbon Strategy for growth and jobs, and organizing them according to the three main above-mentioned priorities (Commission, $\operatorname{COM}(2005)$ 330). Some of the key actions it recommends are: support for knowledge and innovation in Europe; reform of state aid policies; better business regulation; the completion of the internal market for services; the completion of an ambitious agreement in the Doha Round; the removal of obstacles to physical, labour and academic mobility; the development of a common approach to economic migration; and support to manage the social consequences of economic restructuring.

While the implementation of the national programmes for growth and jobs requires stronger coordination among government bodies, the 
Community Lisbon Programme requires similarly higher levels of coordination by the European Commission and the relevant formations of the Council of Ministers, namely: the Economic and Financial Affairs Council (Ecofin), Employment and Social Affairs, Competitiveness, Education and Environment. As regards the European Parliament (EP), there exists an internal coordination procedure involving the various EP commissions; and national parliaments should consider instituting mechanisms to coordinate their relevant commissions.

\section{Developing Financial Incentives}

Financial instruments are also the object of various reforms to align them with the political priorities of the Lisbon Strategy. The Community framework for state aid is being reviewed to promote a more horizontal approach, focusing on research and development (R\&D), innovation and human capital; the European Investment Bank (EIB) and the European Investment Fund (EIF) are also deploying new instruments to the strategy for growth and jobs, and were asked to focus specially on the needs of innovative small and medium-sized enterprises (SMEs) in Europe; the Community programmes can also play an important role as catalysts for national programmes for growth and jobs. The Seventh Framework Programme for Research and Technological Development, the Community Programme for Competitiveness and Innovation, and the Community Programme for Lifelong Learning are particularly relevant here. However, the scope of these programmes was limited severely with the final agreement on the Community budget in December 2005, a major debate about this budget being scheduled for 2008. Finally, the Community Strategic Guidelines for the Cohesion Policy proposed by the European Commission were closely aligned with the integrated guidelines for the Lisbon Strategy, covering the three main goals of making Europe and its regions more attractive places to invest and work, of promoting knowledge and innovation for growth, and of creating more and better jobs (Commission, $\operatorname{COM}(2005)$ 299).

Beyond this, the Stability and Growth Pact underwent reforms that may be very relevant for the Lisbon Strategy (Council 7619/05). Macroeconomic stability remains a central concern, the limit on public deficits and public debt remains at 3 per cent and 60 per cent as a ratio of gross domestic product (GDP), and procyclical fiscal policies are discouraged, but there is a new emphasis on fostering economic growth and on the sustainability of the public debt in order to deal with demographic trends. Further, the Lisbon goals of reforming social protection systems, and redirecting public expenditure to key investments with growth potential (in 
$\mathrm{R} \& \mathrm{D}$, innovation and human capital), are among the relevant factors to be taken into account when assessing public deficits (either below or above 3 per cent), or when defining adjustment trajectories in the case of the excessive deficit procedure.

\section{I.5 THE INSTITUTIONAL INSTRUMENTS OF THE LISBON PROCESS}

The implementation of the Lisbon Agenda has given rise to a political and social process involving, in a progressively organized way, the following institutions and actors: the European Council, in its several annual meetings with a particular relevance for its spring meeting; the Council, in seven of its formations: General Affairs, Ecofin, Competitiveness, Employment, Education, Environment, Energy and Telecommunications; their Council committees and groups, which are also involved; the European Commission, involving 15 out of 27 commissioners and 17 directoratesgeneral, with a smaller group of 'Lisbon' commissioners meeting on a more regular basis; the European Parliament, involving six of its committees; national parliaments, involving at least their European affairs committees, which organize a yearly Lisbon conference with the European Parliament; the European Economic and Social Committee and its Lisbon network of economic and social councils in the Member States that they exist in; the Committee of Regions and its Lisbon platform involving more than a hundred regions; the European confederations of social partners, representing their counterparts at the national level and meeting regularly with the other European institutions in the Tripartite Social Summit; and last but not least, the national governments with the involvement of several ministers and ministries as well as the prime ministers. A horizontal network of top officials is also emerging in all Member States due the role of a Lisbon coordinator, a minister or a top official reporting to a minister or the prime minister.

Beyond this institutional setting, there is a diversified network of civil society organizations in various areas, which in various ways follow and feed into the development of the Lisbon Agenda. Most of them are probably not aware of the European agenda, but only of its translation into concrete measures at the national level. The same happens with many political and media actors at the national level. This explains why the level of 'ownership' remains quite low, albeit with many differences across Member States. Still, quite a large network of civil society leaders across Europe is explicitly connecting the Lisbon Agenda with their regular work. 
The Lisbon Treaty can create the institutional conditions for better governance of the Lisbon process, by clarifying Union competences, improving horizontal coordination, and fostering the decision-making process and strengthening its democratic legitimacy. It remains to be seen to what extent this potential will be taken advantage of.

\section{I.6 POLICY ACHIEVEMENTS AND KEY ISSUES}

The relaunching of the Lisbon Strategy focused more on national level implementation. Within the institutional framework defined in 2005, the EU Member States have prepared and implemented their national reform programmes. This has been the largest coordinated process of economic reform ever attempted in Europe. The purpose was to adapt a set of common priorities to foster growth and employment to each national context, and to prepare Europe for globalization. As these national programmes show, there are many reforms under way throughout Europe (see Table I.2). But are they heading in the right direction, and do they have the necessary scope?

The central question seems clear: how can Europe develop a knowledgeintensive and low-carbon economy and grow faster, creating more and better jobs and sustaining social inclusion, in today's globalized economy? We should acknowledge that there is a real problem here, because Europe is currently the economic bloc with the lowest potential growth. The answer also seems simple: Europe needs to explore new markets, increase competitiveness by investing in knowledge, as well as expand and train the employed population. From this viewpoint, what conclusions can we draw from the national reform programmes?

As regards new markets, there is the progress resulting from the enlargement and globalization strategies adopted by some European countries and companies. One example is the current race to invest in China or India. However, many other steps need to be taken to reach an agreement in the World Trade Organization (WTO) Doha Round; to develop long-term strategic partnerships with Europe's key external partners; to implement the reached agreement in the services directive; to turn the next generation of structural funds into more powerful tools to enable the less-developed regions to catch up; and to use the eurozone to coordinate more strongly macroeconomic policies for investment and growth.

In terms of competitiveness, what is at stake is the redeployment of European economies to engage in higher added-value activities, whatever the sector, be it biotech, information technologies, business services, automotive, textile or tourism industries. More public and private investment in 
Table I.2 The Lisbon Agenda: relative achievements and failures as of 2007

\begin{tabular}{|c|c|c|}
\hline Policy field & (Relative) achievements & (Relative) failures \\
\hline $\begin{array}{l}\text { Information } \\
\text { society }\end{array}$ & $\begin{array}{l}\text { - Schools connected } \\
\text { with Internet } \\
\text { - Public services: access via } \\
\text { Internet } \\
\text { - Extension of broadband }\end{array}$ & - Scale in content industries \\
\hline Research & $\begin{array}{l}\text { - European research networks } \\
\text { - European research } \\
\text { infrastructure } \\
\text { - Technology platforms } \\
\text { - European Institute of } \\
\text { Technology }\end{array}$ & $\begin{array}{l}\text { - Community patent } \\
\text { - Mobility of researchers }\end{array}$ \\
\hline Innovation & $\begin{array}{l}\text { - Joint technology initiatives } \\
\text { - Clusters } \\
\text { - One stop-shop for start-ups } \\
\text { - Galileo }\end{array}$ & $\begin{array}{l}\text { - Interface business- } \\
\text { universities } \\
\text { - Venture capital }\end{array}$ \\
\hline Lifelong learning & $\begin{array}{l}\text { - Extension of early-school } \\
\text { education } \\
\text { - Extension of vocational and } \\
\text { technological education }\end{array}$ & $\begin{array}{l}\text { - Modernization of } \\
\text { universities } \\
\text { - Extension of training for } \\
\text { adults }\end{array}$ \\
\hline Single market & $\begin{array}{l}\text { - Telecommunications } \\
\text { - Single sky } \\
\text { - Financial services } \\
\text { - Services directive } \\
\text { - Reducing red tape }\end{array}$ & $\begin{array}{l}\text { - Energy } \\
\text { - Portability of pensions } \\
\text { - Better regulation }\end{array}$ \\
\hline Trade & - Bilateral agreements & - Doha Round \\
\hline Employment & $\begin{array}{l}\text { - Net jobs creation } \\
\text { ( } 15 \text { million) } \\
\text { - Modernization of } \\
\text { employment services } \\
\text { - Women employment rate } \\
\text { - Restructuring management }\end{array}$ & $\begin{array}{l}\text { - Flexicurity } \\
\text { - Employment of young } \\
\text { people } \\
\text { - Immigration management }\end{array}$ \\
\hline Social protection & - Pensions reform & - Active ageing \\
\hline Social inclusion & - Childcare services & - Poverty rate reduction \\
\hline Environment & $\begin{array}{l}\text { - Environmental awareness } \\
\text { - Emissions trade scheme }\end{array}$ & - Renewable energies \\
\hline
\end{tabular}

$\mathrm{R} \& \mathrm{D}$ is crucial to step up this transition to a knowledge-intensive economy. This can be achieved with better infrastructure, more training and mobility of researchers, and more fiscal incentives. But this is not enough to turn knowledge into value. What is also missing in many European countries is 
a more ambitious development of their innovation systems, connecting companies and universities to create promising clusters and partnerships.

European employment policy has another focus now: not only to reduce unemployment, but also to increase the number of employed people, who can thereby contribute to sustaining social protection systems. For this reason, many countries are activating their employment services to make jobs or training proposals, expanding childcare and testing the first measures for active ageing. Nevertheless, something deeper is at stake: the reorganization and coordination of employment, training and social protection policies to support people during their life cycle, at a time when people are making increasingly diverse choices. This will make it easier to introduce more flexibility to the labour market, according to the so-called flexicurity models.

In the meantime, the original stamp of the Lisbon Strategy on the social dimension should remain clear. The best tool to adapt to change is lifelong learning. There is improvement in terms of the rate of workers who can access lifelong learning, or in terms of the share of young people completing secondary education. But, again, there is something broader at stake: building a lifelong learning system with access points in schools, companies and households, providing more tailor-made education and training services. Universities have a particular responsibility to respond to much more diversified demands.

A reorientation of national and European policies seems to be under way, but this needs to go much further and pass another crucial test: redirecting financial means. The recent review of the Stability and Growth Pact will be under scrutiny. Certainly, fiscal consolidation and improved sustainability of social protection systems is at stake; but redirecting public expenditure, tax systems and Structural Funds to the future-oriented priorities of investing in research, innovation and human capital are also crucial issues.

We can draw another conclusion from the review of the national reform programmes: differences in implementation are now very clear when we compare policy fields or Member States. The best general performance in growth, jobs, innovation, social inclusion and the environment seems to be happening in the countries that have implemented this Agenda more consistently. This is something that needs to be debated in each country.

\section{NOTE}

1. These programmes were prepared as of November 2005 and are available, together with the European Commission assessment, at: http://europa.eu.int/growthandjobs/ index_en. htm. 
Europe, globalization and the Lisbon Agenda

\section{BIBLIOGRAPHY}

Boyer, R. (1998), The Search for Labour Market Flexibility, Oxford: Oxford University Press.

Council of the European Union (2000a), Conclusions of the Lisbon European Council, SN 100/00, 23-24 March 2000.

Council of the European Union (2000b), The Ongoing Experience of the Open Method of Co-ordination, Note of the Portuguese Presidency of the Union, 9088/00, 14 June 2000.

Council of the European Union (2005a), Conclusions of the Brussels European Council, 7619/05, 22-23 March 2005.

Council of the European Union (2005b), Conclusions of the Brussels European Council, 10255/05, 16-17 June 2005.

Council of the European Union (2005c), Integrated Guidelines: Broad Economic Policy Guidelines, 10667/05, 28 June 2005.

Council of the European Union (2005d), Council Decision on Guidelines for the employment policies of the Member States, 10205/05, 5 July 2005.

Council of the European Union (2008), Conclusions of the Brussels European Council, 7652/08, 13-14 March 2008.

European Commission (2005a), Cohesion Policy in Support of Growth and Jobs: Community Strategic Guidelines, 2007-2013, COM(2005) 299 final, 05.07.2005.

European Commission (2005b), Common Actions for Growth and Employment: The Community Lisbon Programme, COM(2005) 330 final, 20.07.2005.

Kok, W. (ed.) (2004), Facing the Challenge: The Lisbon Strategy for Growth and Employment, Report of the High Level Group, Brussels: European Commission.

Rodrigues, M.J. (ed.) (2000), International Hearing for the Portuguese Presidency of the European Union, Centro Cultural de Belém, 3-4 December 1999, Lisbon: Gabinete do Primeiro Ministro.

Rodrigues, M.J. (ed.) (2002), The New Knowledge Economy in Europe: A Strategy for International Competitiveness and Social Cohesion, with the collaboration of R. Boyer, M. Castells, G. Esping-Andersen, R. Lindley, B.A. Lundvall, L. Soete, M. Telò and M. Tomlinson, Cheltenham, UK and Northampton, MA, USA: Edward Elgar.

Rodrigues, M.J. (2003), European Policies for a Knowledge Economy, Cheltenham, UK and Northampton, MA, USA: Edward Elgar.

Rodrigues, M.J. (ed.) (2004a), The Lisbon Strategy: A Follow-up for Researchers, SSHERA Project Final Report, European Commission's Advisory Group on Social Sciences, SSHERA Project, EU 6th Framework Programme RTD.

Rodrigues, M.J. (2004b), 'For the Mid-Term Review of the Lisbon Strategy', Background Paper 4, in M.J. Rodrigues (ed.), The Lisbon Strategy - a Follow-up for Researchers, SSHERA Project Final Report, European Commission's Advisory Group on Social Sciences, SSHERA Project, EU 6th Framework Programme RTD.

Rodrigues, M.J., G. Arbix, J.C. Ferraz, S. Fisher, F. Godement, G. Grevi, C. Huang, L. Soete, M. Telò, A. Valladão, A. Vasconcelos, C. Wagner and H. Zhou (eds) (2007), Developing the External Action of the European Union. New Instruments and New Global Players, Portuguese Presidency of the European Union, Lisbon: Gabinete do Primeiro Ministro. 
Sapir, A. (2004), An Agenda for a Growing Europe: The Sapir Report, Oxford: Oxford University Press.

http://www.europa.eu/growthandjobs/.

http://www.mariajoaorodrigues.eu.

See further bibliography in Appendix 4 of this book. 
Maria João Rodrigues - 9781848446083 Downloaded from PubFactory at 04/26/2023 11:19:24AM via free access 